\title{
Preparation of Cerium Dioxide Thin Films via Sol-Gel Process and Their Characteristics as Electrical Buffer Layers
}

\author{
Kiyoshi KURIBAYASHI, Rina UCHIKAWA and Kiyoshi TAKAHASHI \\ Teikyo University of Science \& Technology, Yatsusawa, Uenohara-machi, Kitatsuru-gun, Yamanashi 409-0193

\begin{abstract}
ゾルーゲル法による二酸化セリウム薄膜の作製と電気的バッファ層としての特性
栗林 清·内川里奈・高橋 清

帝京科学大学, 409-0193 山梨県北都留郡上野原町八ツ沢
\end{abstract}

\begin{abstract}
$\mathrm{CeO}_{2}$ thin films were prepared on $\mathrm{Si}(100)$ and $\mathrm{Si}(111)$ substrates from cerium acetate monohydrate via solgel process. The thin films were crystallized at approximately $700^{\circ} \mathrm{C}$ and had polycrystalline microstructure. Scanning electron microscopy (SEM) observation showed that those films consisted of small grains of 60$70 \mathrm{~nm}$ in diameter and had even surfaces. $\mathrm{SrTiO}_{3}$ films with a platinum top electrode were formed on $\mathrm{Pt} / \mathrm{Si}$ and $\mathrm{Pt} / \mathrm{CeO}_{2} / \mathrm{Si}$ substrates. Current voltage $(I-V)$ characteristics of the $\mathrm{SrTiO}_{3}$ films were measured on $\mathrm{Pt} /$ $\mathrm{SrTiO}_{3} / \mathrm{Pt} / \mathrm{Si}$ and $\mathrm{Pt} / \mathrm{SrTiO}_{3} / \mathrm{Pt} / \mathrm{CeO}_{2} / \mathrm{Si}$ structures. The leakage current density for the former sample was approximately $6.6 \times 10^{-6} \mathrm{~A} / \mathrm{cm}^{2}$ under the applied electric field of $9.4 \times 10^{4} \mathrm{~V} / \mathrm{cm}$. An increase in the applied electric field above $9.4 \times 10^{4} \mathrm{~V} / \mathrm{cm}$ resulted in a marked increase in the leakage current. The leakage current for the latter sample was $4.1 \times 10^{-6} \mathrm{~A} / \mathrm{cm}^{2}$ under $2.5 \times 10^{5} \mathrm{~V} / \mathrm{cm}$. The $I-V$ characteristics of the $\mathrm{SrTiO}_{3}$ films were improved by the use of the $\mathrm{CeO}_{2}$ film as an intermediate layer.
\end{abstract}

[Recevied June 8, 1998; Accepted January 20, 1999]

Key-words : $\mathrm{CeO}_{2}$, Thin films, Sol-gel processing, Buffer layer

1. Introduction

Cerium dioxide, $\mathrm{CeO}_{2}$, has a fluorite structure and is an important oxide material with good mechanical, chemical and thermal stabilities. $\mathrm{CeO}_{2}$ films have been widely used as optical coatings, ${ }^{1)}$ heat mirrors, ${ }^{2)}$ buffer materials for epitaxial high- $T_{\mathrm{c}}$ superconducting oxide thin films on silicon and sapphire, ${ }^{3), 4)}$ and insulating layers in metal-oxide-semiconductor transistors ${ }^{5)}$ and high- $T_{\mathrm{c}}$ superconducting field effect devices. ${ }^{6}$ ) To date, $\mathrm{CeO}_{2}$ thin films have been prepared by using rf magnetron sputtering, ${ }^{7)}$ electron beam evaporation ${ }^{8,9)}$ and metal-organic chemical vapor deposition methods. ${ }^{10)}$ However, to the authors' knowledge, there is no report on the growth of $\mathrm{CeO}_{2}$ thin films by sol-gel process. For the increased design choices of device fabrication, it is desirable to examine various deposition techniques and substrates in order to investigate growth behavior of the thin films.

This paper reports the crystallization and structural evolution of $\mathrm{CeO}_{2}$ thin films fabricated on $\mathrm{Si}(100)$ and $\mathrm{Si}(111)$ substrates by sol-gel process. In order to study the role of $\mathrm{CeO}_{2}$ thin film as an intermediate layer, $I-V$ characteristics of $\mathrm{SrTiO}_{3}$ films formed on $\mathrm{Pt} / \mathrm{Si}$ and $\mathrm{Pt} /$ $\mathrm{CeO}_{2} / \mathrm{Si}$ were measured. The interfaces of $\mathrm{SrTiO}_{3} / \mathrm{Si}$ and $\mathrm{SrTiO}_{3} / \mathrm{CeO}_{2} / \mathrm{Si}$ were also studied by means of Auger electron spectroscopy (AES).

\section{Experimental}

Cerium(III) acetate monohydrate, $\mathrm{Ce}\left(\mathrm{CH}_{3} \mathrm{COO}\right)_{3} \cdot \mathrm{H}_{2} \mathrm{O}$, was dissolved in acetic acid at $60^{\circ} \mathrm{C}$ for $30 \mathrm{~min}$ in flowing argon gas. One volume of 2-aminoethanol was added to four volumes of the cerium acetate solution to prevent rapid hydrolysis of cerium acetate; addition of smaller amounts of 2 -aminoethanol resulted in poor stability of the solution, and addition of lager amounts of 2-aminoethanol lead to poor wettability of the solution to the $\mathrm{Si}$ substrates. The solution was then refluxed at $110^{\circ} \mathrm{C}$ for $3 \mathrm{~h}$ in flowing $\mathrm{Ar}$ gas. In this way, the starting solution containing $\mathrm{Ce}\left(\mathrm{CH}_{3} \mathrm{COO}\right)_{3}$ of about $0.15 \mathrm{~mol} / 1$ was prepared. The solution was then coated on $\mathrm{Si}(100)$ and $\mathrm{Si}(111)$ substrates by spin coating at $1500 \mathrm{rpm}$ for $20 \mathrm{~s}$ and dried in air at $200^{\circ} \mathrm{C}$ for each layer. In order to remove the native oxide layer of $\mathrm{Si}$, the substrates were etched in 20 vol\% HF solution at room temperature for $3 \mathrm{~min}$ prior to the coating. Films of desired thickness could be obtained by multiple coating processes. The films were then heated in air at temperatures between 600 and $900^{\circ} \mathrm{C}$ for $3 \mathrm{~h}$. After firing, samples were examined by means of X-ray $\theta-2 \theta$ diffraction (XRD) and scanning electron microscopy (SEM).

In order to study the role of the $\mathrm{CeO}_{2}$ thin film as an intermediate layer between $\mathrm{SrTiO}_{3}$ and $\mathrm{Si}, \mathrm{SrTiO}_{3}$ with $\mathrm{Pt}$ top electrode were formed on $\mathrm{Pt} / \mathrm{Si}$ and $\mathrm{Pt} / \mathrm{CeO}_{2} / \mathrm{Si}$ substrates. Approximately 100-nm thick Pt electrodes were sputter deposited at $500^{\circ} \mathrm{C}$ in flowing $\mathrm{Ar}$ and $\mathrm{O}_{2}$ gasses $(\mathrm{Ar}$ : $\mathrm{O}_{2}=4: 1$ ). The ambient pressure during sputter deposition was $0.3 \mathrm{~Pa}^{\mathrm{S}} \mathrm{SrTiO}_{3}$ was deposited on the Pt electrode by the sol-gel method using a solution which was prepared by dissolving strontium acetate 0.5 hydrate and titanium tetraisopropoxide in acetic acid and 2-methoxyethanol, respectively. These two solutions were mixed and refluxed at $110^{\circ} \mathrm{C}$ for $12 \mathrm{~h}$ in flowing $\mathrm{N}_{2}$ gas before the deposition. The heat treatment was conducted in air at $800^{\circ} \mathrm{C}$ for $3 \mathrm{~h}$. Typical polycrystalline $\mathrm{SrTiO}_{3}$ patterns were obtained by XRD measurements for the samples of $\mathrm{SrTiO}_{3} / \mathrm{Pt} / \mathrm{Si}$ and $\mathrm{SrTiO}_{3} / \mathrm{Pt} / \mathrm{CeO}_{2} / \mathrm{Si}$. $\mathrm{SrTiO}_{3}$ films of 120 and $160 \mathrm{~nm}$ in thickness were prepared for the electrical measurements. $\mathrm{Pt}$ top electrode with $0.096 \mathrm{~cm}^{2}$ were sputter deposited on $\mathrm{SrTiO}_{3} / \mathrm{Pt} / \mathrm{Si}$ and $\mathrm{SrTiO}_{3} / \mathrm{Pt} / \mathrm{CeO}_{2} / \mathrm{Si}$ in order to measure $I-V$ characteristics of the $\mathrm{SrTiO}_{3}$ films with $\mathrm{Pt} / \mathrm{SrTiO} \mathrm{Ti}_{3} / \mathrm{Pt} /$ $\mathrm{Si}$ and $\mathrm{Pt} / \mathrm{SrTiO}_{3} / \mathrm{Pt} / \mathrm{CeO}_{2} / \mathrm{Si}$ in both structures. Since it is well-known that $100-\mathrm{nm}$ thick $\mathrm{Pt}$ film does not prevent counterdiffusion of $\mathrm{SrTiO}_{3}$ and $\mathrm{Si}$, ${ }^{11)}$ AES measurements were conducted on the samples with $\mathrm{SrTiO}_{3} / \mathrm{Si}$ and $\mathrm{SrTiO}_{3} / \mathrm{CeO}_{2} / \mathrm{Si}$ structures to study the effect of $\mathrm{CeO}_{2}$ layer to the counterdiffusion of $\mathrm{SrTiO}_{3}$ and $\mathrm{Si}$.

\section{Results and discussion}

Thickness of the $\mathrm{CeO}_{2}$ films, determined by SEM cross sectional observation, increased in proportion to the 
number of coating cycles. The average increase in film thickness per each coating cycle was about $30 \mathrm{~nm}$, and the thickness of the films studied was about $120 \mathrm{~nm}$. Figure 1 shows the XRD patterns of the $\mathrm{CeO}_{2}$ films on $\mathrm{Si}(100)$ that were heat-treated at temperatures from $700^{\circ}$ to $900^{\circ} \mathrm{C}$ for 3 h. The films heated at $600^{\circ} \mathrm{C}$ were amorphous. The films were crystallized at approximately $700^{\circ} \mathrm{C}$ and had polycrystalline microstructure. The $\mathrm{CeO}_{2}$ films formed on $\mathrm{Si}(111)$ were also crystallized at approximately $700^{\circ} \mathrm{C}$ and had polycrystalline microstructure. No difference was found in crystallographical texture or crystallization temperature between the $\mathrm{CeO}_{2}$ films deposited on $\mathrm{Si}(100)$ and $\mathrm{Si}(111)$ substrates. The full width at half maximum (FWHM) values of $0.40,0.27$ and $0.25^{\circ}$ were obtained from the (111) peaks of the $\mathrm{CeO}_{2}$ films grown on $\mathrm{Si}(100)$ substrates at $700^{\circ}, 800^{\circ}$ and $900^{\circ} \mathrm{C}$, respectively. Films with good crystallinity were obtained above $800^{\circ} \mathrm{C}$. Figure 2 shows SEM micrographs of the surface and cross section of the $\mathrm{CeO}_{2}$ films heated at $800^{\circ} \mathrm{C}$ for $3 \mathrm{~h}$. The photographs showed that the films had even surface and consisted of small grains of 60-70 $\mathrm{nm}$ in diameter.

$I-V$ characteristics of the $\mathrm{SrTiO}_{3}$ films are shown in Fig. 3 for the samples with $\mathrm{Pt} / \mathrm{SrTiO}_{3} / \mathrm{Pt} / \mathrm{Si}$ and $\mathrm{Pt} /$ $\mathrm{SrTiO}_{3} / \mathrm{Pt} / \mathrm{CeO}_{2} / \mathrm{Si}$ structures. The leakage current density for the former sample was approximately $6.6 \times 10^{-6} \mathrm{~A}$ / $\mathrm{cm}^{2}$ under the applied electric field of $9.4 \times 10^{4} \mathrm{~V} / \mathrm{cm}$. An increase in applied electric field above $9.4 \times 10^{4} \mathrm{~V} / \mathrm{cm}$ resulted in a marked increase in the leakage current. The thickness of the $\mathrm{SrTiO}_{3}$ layer in the former sample was $\sim 160 \mathrm{~nm}$. When the thickness of the $\mathrm{SrTiO}_{3}$ was less than $120 \mathrm{~nm}$, the leakage current density further increased up to the order of $10^{-3} \mathrm{~A} / \mathrm{cm}^{2}$. For the latter sample, on the otherhand, the leakage current density of the $\mathrm{SrTiO}_{3}$ film was $4.1 \times 10^{-6} \mathrm{~A} / \mathrm{cm}^{2}$ under $2.5 \times 10^{5} \mathrm{~V} / \mathrm{cm}$, though the thickness of the $\mathrm{SrTiO}_{3}$ film was $\sim 120 \mathrm{~nm}$. Thus the $I-V$ characteristics of the $\mathrm{SrTiO}_{3}$ films were thus improved by the use of the sol-gel derived $\mathrm{CeO}_{2}$ film as an intermediate layer.

Figures 4(a) and (b) show the depth profiles of AES for the samples with $\mathrm{SrTiO}_{3} / \mathrm{Si}$ and $\mathrm{SrTiO}_{3} / \mathrm{CeO}_{2} / \mathrm{Si}$ structures, respectively. Sr was not detected in these experiments. Figure 4 (a) shows that diffusion of $\mathrm{Si}$ into $\mathrm{SrTiO}_{3}$ layer and diffusion of $\mathrm{Ti}$ and $\mathrm{O}$ into $\mathrm{Si}$ substrate occurred on the sample with $\mathrm{SrTiO}_{3} / \mathrm{Si}$ structure. $\mathrm{O}$ in $\mathrm{SrTiO}_{3}$ decreased markedly near the interface of $\mathrm{SrTiO}_{3} / \mathrm{Si}$.

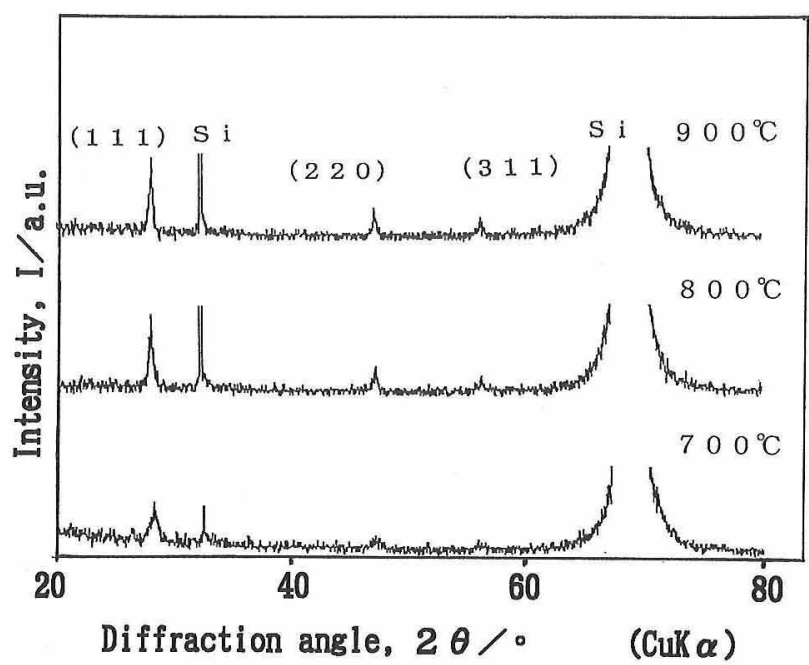

Fig. 1. XRD patterns of the $\mathrm{CeO}_{2}$ thin films formed on $\mathrm{Si}(100)$ at various temperatures.
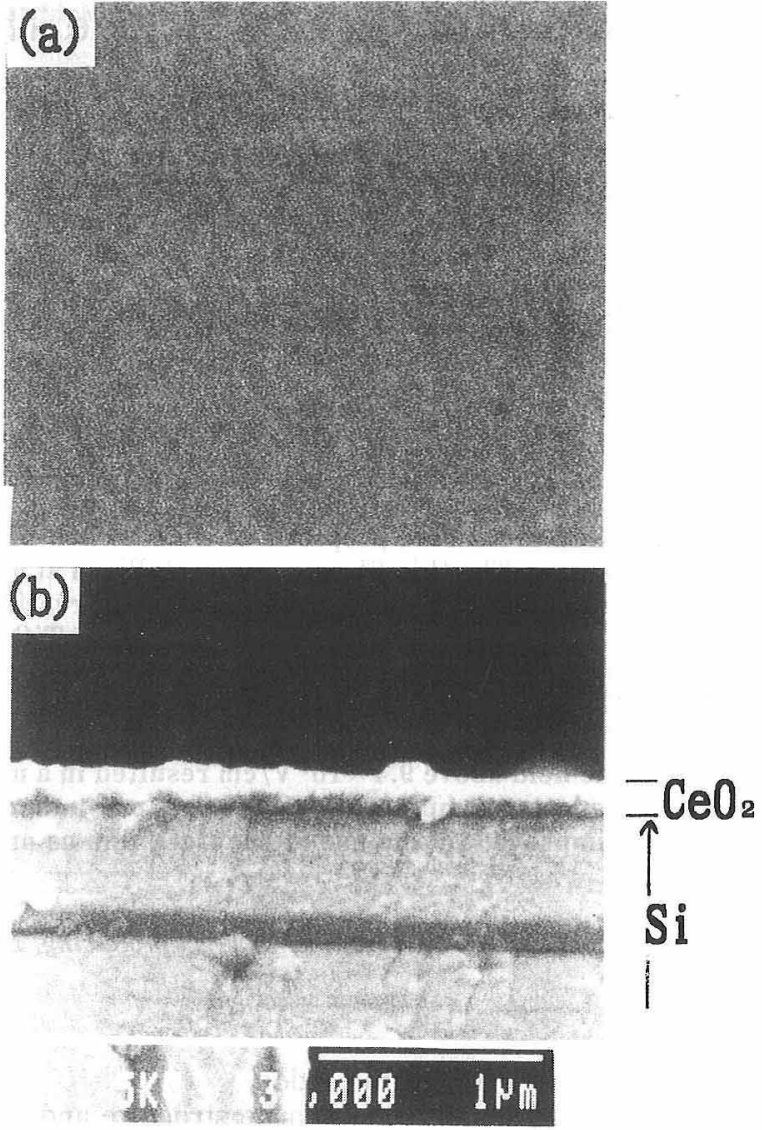

Fig. 2. SEM photographs of the $\mathrm{CeO}_{2}$ thin films formed on $\mathrm{Si}(100)$ at $800^{\circ} \mathrm{C}$ for $3 \mathrm{~h}$. (a) surface, (b) cross section.

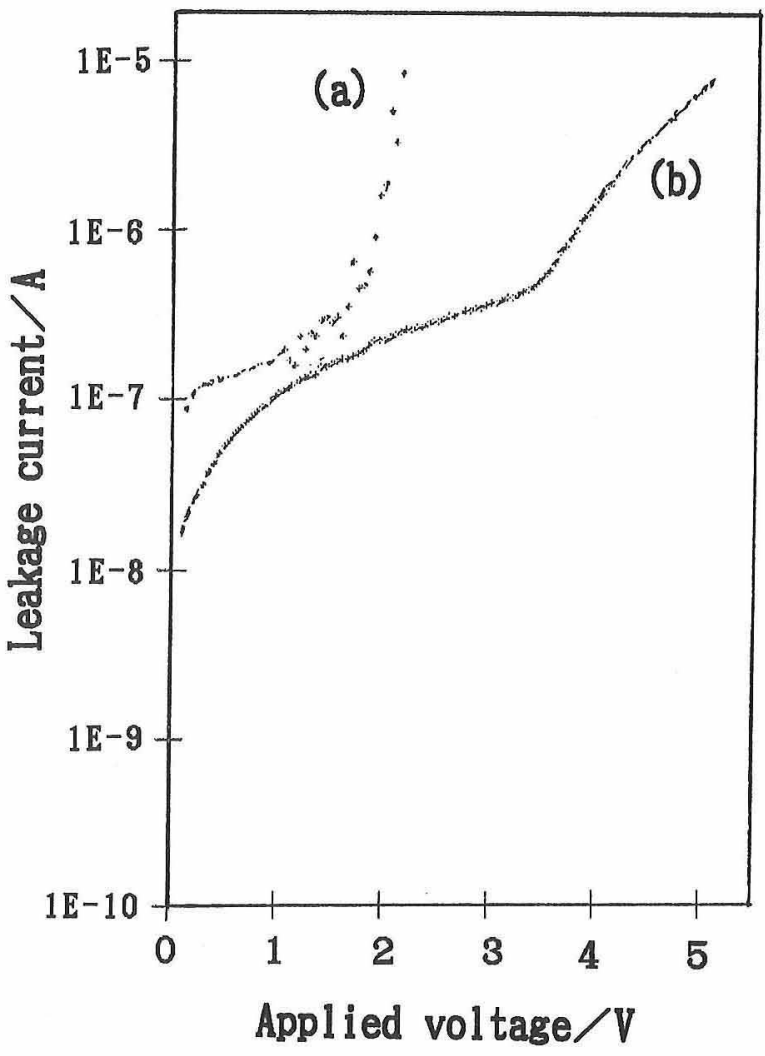

Fig. 3. Current-voltage characteristics of the $\mathrm{SrTiO}_{3}$ films for the samples with (a) $\mathrm{Pt} / \mathrm{SrTiO}_{3} / \mathrm{Pt} / \mathrm{Si}$ and (b) $\mathrm{Pt} / \mathrm{SrTiO}_{3} / \mathrm{Pt}$ / $\mathrm{CeO}_{2} / \mathrm{Si}$ structures. 

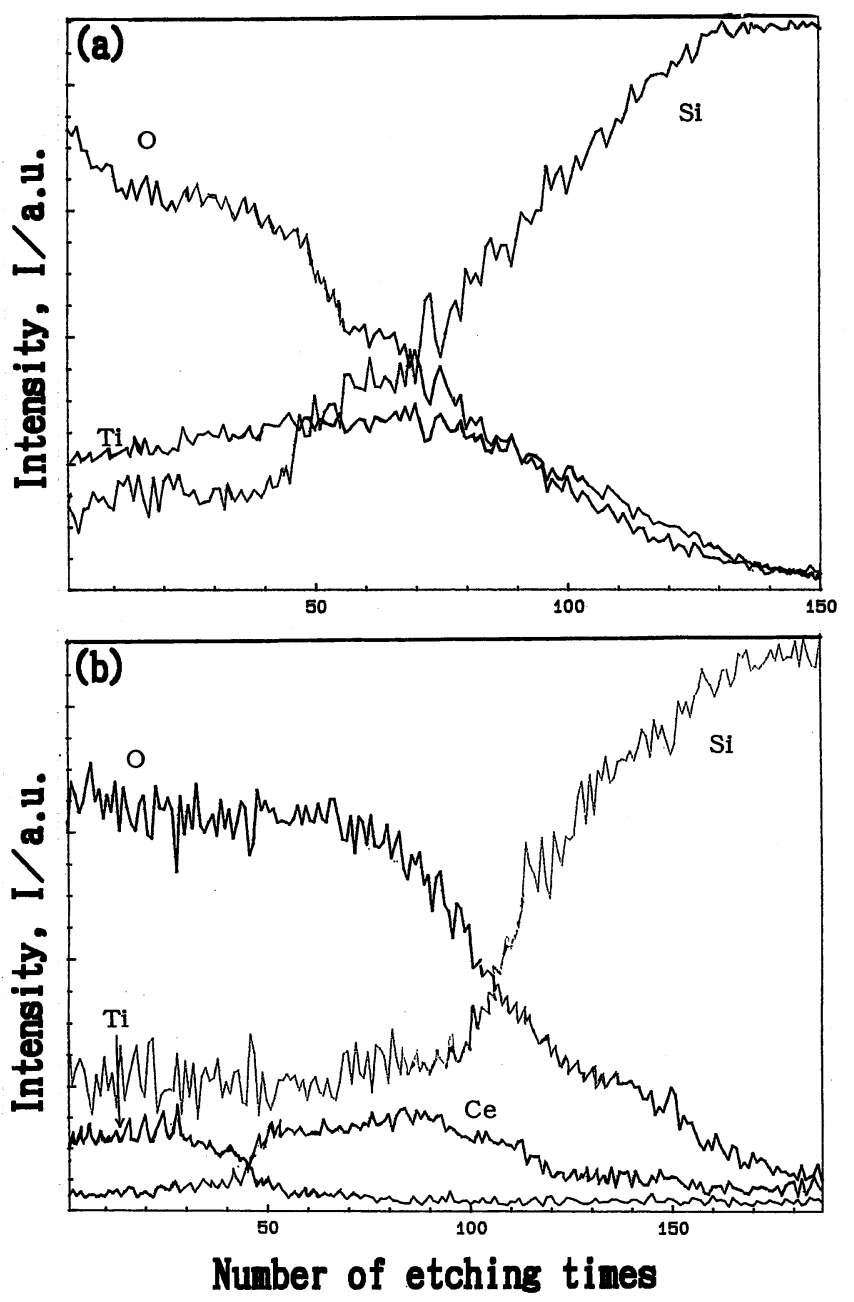

Fig. 4. AES depth profiles of (a) $\mathrm{SrTiO}_{3} / \mathrm{Si}$ and (b) $\mathrm{SrTiO}_{3} /$ $\mathrm{CeO}_{2} / \mathrm{Si}$. The samples were etched by $\mathrm{Ar}^{+}$beam.

Figure 4 (b), on the other hand, shows that little diffusion of $\mathrm{Si}$ into $\mathrm{SrTiO}_{3}$ layer and $\mathrm{Ti}$ into $\mathrm{Si}$ substrate was observed by AES measurement on the sample with $\mathrm{CeO}_{2}$ intermediate layer. Intensity of the AES signals of oxygen was almost constant throughout the $\mathrm{SrTiO}_{3}$ layer on the sample with the $\mathrm{CeO}_{2}$ intermediate layer. Since an increase in the leakage current of $\mathrm{SrTiO}_{3}$ is thought to be influenced largely by oxygen vacancies in $\left.\mathrm{SrTiO}_{3}, 12\right), 13$ ) the difference in the $I-V$ characteristics of the $\mathrm{SrTiO}_{3}$ layers between the $\mathrm{Pt} / \mathrm{SrTiO}_{3} / \mathrm{Pt} / \mathrm{Si}$ and $\mathrm{Pt} / \mathrm{SrTiO}_{3} / \mathrm{Pt} / \mathrm{CeO}_{2} / \mathrm{Si}$ structures might mainly result from the difference of oxygen deficiencies in $\mathrm{SrTiO}_{3}$. The leakage current of our samples was larger than reported values for well fabricated $\mathrm{SrTiO}_{3}$ with $\sim 100 \mathrm{~nm}$ in thickness, $\sim 10^{-8} \mathrm{~A} / \mathrm{cm}^{2},{ }^{13), 14)}$ because preparation conditions of $\mathrm{Pt}$ electrodes and $\mathrm{SrTiO}_{3}$ were not thoroughly investigated in the present experiments. It is, however, obvious that $I-V$ characteristics of $\mathrm{SrTiO}_{3}$ was improved markedly by the use of the sol-gel derived $\mathrm{CeO}_{2}$ film as an intermediate layer between $\mathrm{SrTiO}_{3}$ and $\mathrm{Si}$.

\section{Conclusions}

$\mathrm{CeO}_{2}$ thin films were prepared on $\mathrm{Si}(100)$ and $\mathrm{Si}(111)$ substrates from $\mathrm{Ce}\left(\mathrm{CH}_{3} \mathrm{COO}\right)_{3} \cdot \mathrm{H}_{2} \mathrm{O}$ via sol-gel process. The films were crystallized approximately at $700^{\circ} \mathrm{C}$ and had polycrystalline microstructure. The films consisted of small grains of $60-70 \mathrm{~nm}$ in diameter and had even surface. The leakage current density of $\mathrm{SrTiO}_{3}$ in $\mathrm{Pt} / \mathrm{SrTiO}_{3} / \mathrm{Pt} / \mathrm{Si}$ structure was approximately $6.6 \times 10^{-6} \mathrm{~A} / \mathrm{cm}^{2}$ under the applied electric field of $9.4 \times 10^{4} \mathrm{~V} / \mathrm{cm}$. An increase in applied electric field above $9.4 \times 10^{4} \mathrm{~V} / \mathrm{cm}$ resulted in marked increase in the leakage current. While, the leakage current density of sample with $\mathrm{CeO}_{2}$ intermediate layer was $4.1 \times 10^{-6} \mathrm{~A} /$ $\mathrm{cm}^{2}$ under $2.5 \times 10^{5} \mathrm{~V} / \mathrm{cm}$. The $I-V$ characteristics of the $\mathrm{SrTiO}_{3}$ films were improved by the use of the sol-gel derived $\mathrm{CeO}_{2}$ film as an intermediate layer.

Acknowledgments We thank Mr. M. Inoue of Teikyo University of Science and Technology, for his assistance in SEM observations.

\section{References}

1) R. P. Netterfield, W. G. Sainty, P. J. Martin and S. H. Sie, Appl. Opt., 24, 2267-72 (1985).

2) M. A. Angadi and K. Nallamshetty, J. Mater. Sci. Lett., 8, 391-94 (1989).

3) R. Haakenaasen, D. K. Fork and J. A. Golovchenko, Appl. Phys. Lett., 64, 1573-75 (1994).

4) B. F. Cole, G. C. Liang, N. Newman, K. Char, G. Zacharchuk and J. Martens, Appl. Phys. Lett., 61, 1727-29 (1992).

5) A. G. Frangoul, K. B. Sundaram and P. Wahid, J. Vac. Sci. Technol., B9, 181-83 (1991).

6) A. Walkenhorst, M. Schmitt, H. Adrian and K. Petersen, Appl. Phys. Lett., 64, 1871-73 (1994).

7) A. G. Zaitsev, G. Ockenfuss, D. Guggi, R. Wordenweber and U. Kruger, J. Appl. Phys., 81, 3069-72 (1997).

8) T. Inoue, Y. Yamamoto and M. Satoh, Jpn. J. Appl. Phys., 35, L1685-88 (1996).

9) H. Koike, T. Uesugi, T. Hirai and Y. Tarui, Jpn. J. Appl. Phys., 36, L515-17 (1997).

10) Z. Lu, R. Hiskes, S. A. DiCarolis, A. Nel, R. K. Route and R. S. Feigelson, J. Cryst. Growth, 156, 227-34 (1995).

11) J. P. Wang, Y. C. Ling, M. H. Yeh, K. S. Liu and I. N. Lin, Appl. Phys. Lett., 68, 3401-03 (1996).

12) J. H. Joo, J. M. Seon, Y. C. Jeon, K. Y. Oh, J. S. Roh and J. J. Kim, Appl. Phys. Lett., 70, 3053-55 (1997).

13) S. Komatsu and K. Abe, Extended Abst., The 54th Autumn Meeting, 1993, Jpn. Soc. Appl. Phys., 28p-R-13 (1993) p. 448.

14) T. Tamura, K. Tkai, H. Noshiro, M. Kimura, S. Otani and M. Yamada, Jpn. J. Appl. Phys., 33, L1697-99 (1994). 